Review

\title{
Profile of Surrounding MicroRNAs in Low Density Lipoprotein Uptake
}

\author{
Maria Elisabete Silva Santos 1,*, Ricardo Sousa de Oliveira Paraense ${ }^{2}$, Eric Artur Cortinhas-Alves ${ }^{3}$, \\ Danilo Leôncio Aguiar Pereira 4. \\ 1 Programa de PósGraduação emGenética Biologia Molecular, Universidade Federal do Pará, Rua Augusto \\ Corrêa, 1 - Guamá, CEP-66075-110, Belém, PA, Brazil. \\ 2 Laborátorio de Farmacologia Molecular; Instituto de Ciências Biologicas, Universidade Federal do Pará, \\ Rua Augusto Corrêa, 1 - Guamá, CEP-66075-110, Belém, PA, Brazil.;pos_ricardo@hotmail.com \\ 3 Laboratory de bioquímica do exercício, departamento de Morfologia e CiênciasFisiologicas, Universidade \\ do Estado do Pará (UEPA), Av. João Paulo II, nº 817, Marco CEP: 66095-049, Belém, PA, \\ Brasil.;prof.erikartur@gmail.com \\ 4 Programa de PósGraduaçãoemAgentesInfecciosos e parasitários, Universidade Federal do Pará, Rua \\ Augusto Corrêa, 1 - Guamá, CEP-66075-110, Belém, PA, Brazil; daniloleon@ufpa.br \\ * Correspondence: Elisabete@ufpa.br; Tel.: +55-91-983400652
}

\begin{abstract}
The atherosclerosis, a chronic and inflammatory disease that occurs when there are high levels of low-density lipoprotein (LDL) on plasma. This important risk factor for development of cardiovascular disease (CVD) is the main cause of death worldwide. MicroRNAs have recently emerged as potential biomarkers and therapeutic target for lipid metabolism disorders. In this review, we will provide profile of surrounding miRNAs that have demonstrated being regulators of PCSK9, LDLR and APOB100 genes. Recent work has identified the mir-148, mir-128, mir-27a/b, mir-185, mir-301, mir-130 as important regulators of this pathway because they decrease supply of LDL receptors through interaction with PCSK9. Inhibition of LDLR expression cause elevation of plasma LDL levels which induces atherosclerosis. While mir-30c, mir-122, mir-34 decrease MTTP, which promotes degradation of APOB100 preventing assembly and secretion of VLDL. We conclude that, when overexpressed, mir-148a, mir128 and mir-27a/b, mir-122 and mir-34 are related to decrease in LDLR, facilitating occurrence of atherosclerosis. While mir-30 has been linked to decreased atherosclerosis. Detection of miRNAs profile could be used in the future as a biomarker for disturbs linked to c-LDL uptake and in future anti-miRNAs therapies may be used in the treatment of atherosclerosis.
\end{abstract}

Keywords: surrounding microRNAs; low-density lipoprotein; atherosclerosis; APOB; PCSK9; LDLR

\section{Introduction}

According to World Health Organization (WHO) around 17 million people die worldwide each year in consequence of cardiovascular diseases, being atherosclerosis the main cause .Atherosclerosis is an inflammatory and chronicle disease that occurs when there is an elevation in Low Density Lipoprotein (LDL) levels on plasma, and it is closely related to pathologies as coronaries syndrome, ischemic heart disease, cerebrovascular disease and peripheral vascular disease, all caused by obstruction arteries due to the accumulation of LDL [1].

The LDL contains in its membrane an apolipoprotein (APOB100) which acts as a ligand of LDL receptor (LDLR) in hepatic cells. Ligand-receptor interaction (LDLR and APOB-100) make LDL vesicles being removed of blood flow and absorbed by hepatocytes by endocitosis, decreasing the risk of Atheroclerosis [2]. Supply of LDLR on the cell surface is regulated by PCSK9 (Protein convertase subtilisina/kexina type 9) which bind to LDL receptors leading to its internalization and degradation by lisossomal vesicles, thus decreasing the supply of receptor and rising plasmatic LDL what contributes to the elevation of plasmatic LDL. 
Studies have reported the importance of a small class of molecules known as microRNAs in regulation of cholesterol metabolism [3-5]. The microRNAs are non-coding single-stranded RNAs of proteins $(22-24 \mathrm{pb})$ very important in post transcriptional genetic regulation, it acts in modulation of gene expression and intercellular communication, thus, interfering in a variety of physiological functions among these the cholesterol metabolism $[4,6]$. Studies shown that microRNAs modulates various pathways for lipid uptake, besides regulating various functions in the endothelial cells (EC), In vascular smooth muscle cells (VSMC), in macrophages, differentiation and proliferation of cardiac cells, glucose metabolism, interfering in the progression of atherosclerosis and other cardiovascular diseases [3, 6-7]. The aim of this review is delineate a profile of circunlating miRNAs that interfere with the uptake of LDL through the regulation of LDLR, APOB-100 and PCSK9 genes that can be used as potential biomarkers for the prognosis and treatment of atherosclerosis.

\section{Biogenesis of miRNAs}

Currently, more than 1.500 miRNAs have been described, previous studies have suggested that up to $60 \%$ of our genes can be regulated by miRNAs, and as a consequence, these small endogenous silencers act as regulators of a number of processes such as cell proliferation, development, angiogenesis and cholesterol metabolism [8-9].

The miRNAs are transcribed from intronic regions of genes encoding proteins or intergenic regions. This transcription is performed by RNA polymerase II, generating a long primary transcript (pri-miRNA) that are stacked and polyadenylated [10].These transcripts are capable of folding into hairpin structures that are recognized by RNA binding proteins DGCR8 (DiGeorge syndrome critical region gene 8). DGCRs carry the miRNAs to Drosha, an endonuclease that cleaves the duplex clusters of pri-miRNAs and transforms them into pre-miRNAs (70 nucleotides) [6,10].Pre-miRNAs bind RNA-exporter proteins, such as exportin-5, and are transported rapidly into the cytoplasm [6].

Once in the cytoplasm, the pre-miRNA is processed by a complex of proteins called RNA-Induced Silencing Complex (RISC) formed by Dicer and Argonalta. Dicer is a double-stranded endonucleases that binds and cleaves the pre-miRNA in 21-23 bp segments forming mature miRNAs, which are brought by the RISC to the target mRNA to be paired with the promoter region (3'UTC) promoting gene silencing [10-11].The perfect match between mRNA and miRNA causes degradation of the target mRNA, but these complementarities may also be imperfect when one or more bases are poorly paired, which represses the translation.This non-specificity causes a single miRNA to have several target mRNAs that can regulate the expression of several genes [12].

\section{Surrounding miRNAs as potential biomarkers and therapeutic targets to CVDs}

It was previously believed that miRNA expression was limited to intracellular endogenous activity. It is now known that miRNAs can be synthesized in specific cells and subsequently secreted into plasma, which facilitates the communication between cells of different tissues [13]. The small size of miRNA molecules, and the fact that they are transported into vesicles such as exosomes, microvesicles and lipoproteins, apoptotic bodies and protein complexes, are characteristics that protect these small molecules from the action of plasmatic RNAses and make the microRNAs more stable than mRNAs and DNAs in plasma [14-15].

Studies show that numerous miRNAs have deregulated expression profiles that vary with pathology and degree of severity. Since then several studies have demonstrated the expression of surrounding miRNAs in CVDs, acute myocardial infarction, coronary diseases, dyslipidemia, obesity, diabetes, hypertension and metabolic syndrome. Thus, a new field of miRNA investigations was opened as potential biomarkers for the prognosis and therapeutic targets for the treatment of CVDs. As demonstrate in table 1 [4, 13, 16-18]. 
Tabela1.Surrounding microRNAs related to atherosclerotic process

\begin{tabular}{lll}
\hline MicroRNAs & Target gene & Pathology \\
\hline Mir-148 & LDLR, ABCA1 & Obesity [19] \\
Mir-130B & LDLR, PPAR-g SREBP1 & \\
Mir-301b & LDLR, ABCA1, SREBP1,S1K1 & Metabolicsyndrome[20] \\
Mir-128a/b & LDLR, ABCA1, SREBP1 & Dyslipidemia [5] \\
Mir-27a/b & LDLR,LPL, PCSK9,SREBP1, SREBP2, & Diabetes [21-22] \\
Mir-122 & APOA1,APOB, APOE3 & Oxidative stress [23] \\
Mir-34 & MTTP & \\
Mir-30c & APOB, HNF4 ALFA & Dyslipidemia [24] \\
Mir-544 & MTTP, APOB & Endothelialdysfunction[25] \\
Mir-1202 & APOB & Hypertension [26-27] \\
\hline
\end{tabular}

\section{Uptake of LDL (Low-density lipoprotein)}

Uptake of LDL by hepatocytes occurs through the interaction of several genes, among them apolipoprotein B-100, a protein present in the membrane of LDL vesicles, which has the function of binding to LDLR, allowing the absorption and degradation of LDL by the liver. However, when there are no LDL receptors, metabolism of LDL does not occur and consequently there is an increase in plasma of c-LDL levels favoring the onset of atherosclerosis.

Availability of LDLR for cholesterol uptake occurs through two pathways, the first one is regulated according to the need for cholesterol that the liver cells present. This regulation occurs through the activation of the binding proteins to the sterol regulatory element (SREBPs). There are three isoforms of SREBP: SREBP1a, SREBP1c (encoded by the SREBF1 gene) and SREBP2 (encoded by the SREBF2 gene) [19, 29-30]. In intracellular medium the SREBP1 and SREBP2 are regulated by cholesterol levels. SREBP1 is responsible for transcription of genes involved in synthesis of fatty acids, phospholipids and triacylglycerols being regulated by insulin and oxysterols. SREBP2 are the main regulator of cholesterol biosynthesis [19, 29-30].

These transcription factors, when inactive, remain attached to the nuclear envelope and to the membranes of the endoplasmic reticulum. In cells with low levels of sterols, SREBP2s are targeted to the golgi complex where they are processed to their mature nuclear form. They are then translocated to the nucleus where the DNA sequences responsible for the synthesis of enzymes involved in the biosynthesis of stereoisomers such as hydroxy-3-methylglutaryl CoA reductase (HMGCR), low density lipoprotein receptor (LDLR) and Proproteinconvertasesubtilisin/kexin type 9 (PCSK9). Elevation of the stereoisomers levels inhibits the maturation of SREBP2 and consequently the inhibition of the synthesis of the same in a feedback system [19, 29, 31].

The second pathway that regulates the availability of LDLR occurs through PCSK9, a serine protein that is expressed and secreted primarily in the liver, kidney and brain [32]. PCSK9 is synthesized as a soluble zymogen (proPCSK9) and requires autocatalysis for its activation and maturation [33]. Once activated, PCSK9 can follow two pathways for the degradation of LDLR. The 
first, PCSK9 can bind to LDLR right after synthesis and direct to lysosomal vesicles [34]. In the second route, surrounding PCSK9 binds to low-density lipoprotein (LDLR) receptors present on the surface of hepatocytes, causing their internalization and degradation within lysosomal vesicles [33]. This affects availability of LDLR on the cell surface and consequently concentration of LDL in plasma [31, 35-36].

Normal functioning of LDL uptake pathway is important for maintenance of normal plasmatic cholesterol levels. Hypercholesterolemia occurs through the excess of plasma LDL, representing one of the most important risk factors for the development of atherosclerosis.

\section{Role of miRNAs in the regulation of PCSK9 and LDLR}

Recently, several miRNAs have been implicated in the regulation of lipid metabolism [37-38]. Several studies have shown that modulation of specific miRNAs can directly influence lipid metabolism through post-transcriptional control of key genes such as LDLR. Currently several miRNAs have been correlated with LDLR expression levels, among which are miR-27a/b, miR-148a, miR-128-1, miR-130b, miR-301b and miR-185 [19, 29, 39].

\section{1. $m i R-148 a, m i R-130 b$ and $m i R-301 b$}

The miR-148a is located in an intergenic region of chromosome 7 and is predominantly expressed in liver. In a study by Wagschal et al. (2015) the expression of miR-148a and miR-130b was increased in the liver of rats fed with a high fat diet, suggesting an evolutionarily conserved binding to the function of lipid metabolism. miR-148a is targeted as a key regulator in hepatic cholesterol clearance modulating the expression of LDLR and ABCA1 of HDL. These studies emphasize the therapeutic potential of these miRNAs in the control of c-LDL levels in dyslipidemias $[5,19,29]$.

Studies indicate that other microRNAs also participate in the regulation of LDLR such as miR-301b and miR-128-1. Wagschal et al., (2015) emphasizes the role of miR-301b in controlling the expression of genes involved in hepatic lipogenesis with the salt-inducible kinase 1 (SIK1), gene responsible for activating SREBP1c. This regulation mechanism interferes with the supply of LDLRs in plasmatic membrane and consequently plasma c-LDL levels. It has been shown that in HepG2 cells transfected with miR-128-1, miR-301b, there was a decrease in the uptake of fluorescently labeled c-LDL (Dil-LDL) compared to non-transfected cells, suggesting that these miRNAs modulate the uptake of LDL-c.

\section{2. $m i R-27 a / b$}

$\mathrm{miR}-27 \mathrm{~b}$ is expressed in the liver and is recently related to the negative regulation of plasma coleterol levels. Zang et al., (2014) reports that miR-27a and miR-27b can influence metabolic pathways of efflux, influx, esterification and cholesterol hydrolysis by regulating several genes, including LDLR and PCSK9 (Vicks et al., 2013). LDLR is one of miR-27a/b targets. A study with wild-type mice using AAV8 vectors showed that the elevation of miR-27b levels by 50 -fold resulted in a reduction in ABCA1 expression by $50 \%$ and LDLR by $20 \%$, however, there was no change in levels of Cholesterol or triglycerides $[4,15]$.

Alvarez et al., (2015) found that overexpression of miR-27 in HepG2 cells caused a $40 \%$ decrease in the supply of LDLR, however, it was observed that interaction between miR-27 and PCSK9 increased in three-fold the expression of PCSK9.

Shirasaki et al. (2013) observed that miR-27a regulates lipid metabolism by inhibiting the expression of several genes, such as the SREBP1, SREBP2 transcription factors responsible for the activation of LDLR and PCSK9 transcription, as well as the inhibition of apolipoproteins expression ApoA1, ApoB100 and ApoE3. Thus, miR-27a regulates lipid metabolism by reducing lipid synthesis and lipid secretion of cells. To determine the effects of overexpression of miR-27b on surrounding lipids, Goedeke et al. (2015) fed wild-type rats with a lipid-rich diet and treated them with $5 \mathrm{mg} / \mathrm{kg}$ injections of anti-27b LNA oligonucleotides. Two weeks after treatment, rats showed increased 
ABCA1 and LDLR expression by $10-20 \%$, these results reinforce how miR-27b regulates the expression of important genes in lipid metabolism and may be a potential target for treatment of CVD.

LPL gene encodes the enzyme lipoprotein lipase, which aids the breakdown of lipoproteins, which normally carry fat molecules from the intestine into the bloodstream. Macrophage-derived lipoprotein lipase (LPL) plays a key role in accelerating lipid accumulation and secretion of proinflammatory cytokines in the atherosclerotic process. Xie et al. (2016) provides evidence that a novel anti-atherogenic role of miR-27 is closely related to the reduction of lipid accumulation and inflammatory response through the negative regulation of LPL gene expression, suggesting a potential strategy for the diagnosis and treatment of atherosclerosis [23].

\section{3. $m i R-185$}

miR-185 is located on chromosome $22 \mathrm{q} 11.2$ and is considered an important regulator of carcinoma cells and neurological disorders [43]. However, more recent work on miR-185 has demonstrated its importance in the metabolism of atherosclerosis and CVDs.

Yu et al. (2016) found that miR-185 levels in patients with diabetes mellitus were significantly higher than those found in healthy controls, it was also demonstrated that there was no correlation between increased miR-185 levels and cardiac function.

miR-185 plays an important role in regulating various targets that play a role in cardiac hypertrophy, an adaptive mechanism of the heart, in response to increased activity or functional overload [44].

Overexpression of miR-185 causes decreased expression of hydroxy-3-methylglutaryl CoA reductase (HMGCR) and low-density lipoprotein (LDLR) receptor [37, 45]. Yang et al. (2014) evidenced that mice with elevated cholesterol had levels of miR-185 expression five times higher than the control group. Induced inhibition of miR-185 caused decreased expression of the SREBP-2, LDLR and PCSK9 genes and HMG-CoA reductase activity. In addition, miR-185 expression was found to be tightly regulated by SREBP-1c, through its binding to a single sterol response element in the miR-185 promoter.

\section{Role of miRNAs in the regulation of apoliprotein АРОВ}

The APOB-100 are important components of the VLDL vesicles, and LDL, has the function of binding to LDL receptors for the absorption of plasma cholesterol by the liver, playing a key role in cholesterol metabolism [46]. After its synthesis, APOB-100 is translocated by the membrane of the endoplasmic reticulum (ER) to the addition of small molecules of lipids and also to avoid their degradation. It is in the RE that APOB100 binds to MTTP (Microsomal triglyceride transfer protein), which adds more phospholipids to APOB100 for the assembly and secretion of lipoproteins [39].

However, it is not yet known specifically which microRNAs are involved in the regulation of this pathway [28]. The microRNA is a major regulator of glucose metabolism, oxidative stress, arterial hypertension and processes such as adipogenesis, cardiac hypertrophy and ischemia, indicating that its expression may be essential for normal cardiac function and structure (Huang et al., 2016, Chen et al. 2016).

The importance of miRNAs in the assembly and secretion of lipoproteins containing APOB is now known. However, it is not yet known specifically which miRNAs are involved in the regulation of this pathway (Basir et al., 2014). miR-30c is a major regulator of glucose metabolism, oxidative stress, arterial hypertension and processes such as adipogenesis, cardiac hypertrophy and ischemia, indicating that its expression may be essential for normal cardiac function and structure [47].

\section{1. $\operatorname{miR}-30$}

One of the functions recently discovered, and therefore little described, is the role of miR-30 in the regulation of lipid metabolism. Previous studies have shown that overexpression of miR-30c 
decreases hepatic MTTP synthesis. Soh et al. (2013) observed that inhibition of miR-30c in Huh7 hepatocytes increased MTTP expression. The secretion and function of APOB100 and lipoproteins remained unchanged, evidencing how miR-30c is an important regulator of plasma c-LDL levels. Overexpression of miR-30c mediated by lentivirus, decreased hepatic MTT expression [26-27]. The absence of formation of MTTP-APOB complex promotes the degradation of APOB in the lumen of the endoplasmic reticulum, which causes compromise in the VLDL assembly [39]. It was observed that mice fed for three weeks on a high fat diet and exhibiting lentivirus-mediated overexpression of miR-30c, remained low c-LDL levels compared to controls. MiR-30c contributed to the decrease of atherosclerosis in APO -/- mice, demonstrating that it is important for the regulation of hepatic and plasma lipid concentrations through the inhibition of lipid synthesis and secretion of lipoproteins containing APOB100 rich in triglycerides [26-27, 47]. Soh et al. (2013) suggest that miR-30 analogues can be used to treat hypercholesterolemia and atherosclerosis in patients who are intolerant to statins.

\section{2. $m i R-122$}

The most abundant microRNA in the liver is miR-122, accounting for about $70 \%$ of all expressed miRNA, responsible for maintaining the hepatic cell phenotype [48]. miR-122 also plays an important role in the regulation of the MTTP and APOB100 pathways. Mice with deletion in the coding region of miR-122 remained with low plasma LDL levels, but developed hepatic steatosis [49]. Inhibition of miR-122 causes assembly impairment and lipoprotein secretion due to inhibition of various genes, such as MTTP which is important in preventing the degradation and lipidation of nascent APOB during the generation of VLDL in the liver [24]. In a study conducted by de Liu et al. (2013), the influence of miR-122 expression on the differentiation of pluripotent stem cells in sperm-like cells in vitro was investigated. The miR-122 interferes in the expression of lipoproteins like APOB and APOA causing the abnormal development of spermatozoa.

Several studies associate the inhibition of miR-122 expression in mice with the reduction of plasma cholesterol and triglyceride levels when compared to controls [50-51]. According to Zampetaki et al. (2012), this decrease in plasma c-LDL is a consequence of increased fatty acid oxidation and decreased hepatic cholesterol synthesis caused by the inhibition of miR-122 through the regulation of fatty acid oxidation related genes [49-50].

Gene expression studies emphasize the importance of miR-122 in the synthesis of VLDL by regulating genes such as MTTP, APOB, APOE, LDLR and SREP1c, demonstrating miR-122 as a potential target for the treatment of lipid disorders [51-52].

\section{3. $m i R-34$}

Another miRNA that has been reported in the regulation of APOB is miR-34 [25]. Recent studies have shown that this miRNA regulates lipid metabolism through genes such as HNF4 $\alpha$, a hepatic hormone-nucleolar receptor that regulates APOB expression. The expression of miR-34 decreases the secretion of LDL, VLDL, which results in hepatic steatosis and decrease in plasma lipid levels. Thus the increase of miR-34a reduces the expression of HNF4 $\alpha$ in the liver by attenuating the development of atherosclerosis in APOE -/- or LDLR -/- mice. These data indicate that the miR-34a-HNF4 $\alpha$ pathway is activated under common metabolic stress conditions and may play a role in plasma lipoprotein metabolism and atherosclerosis protection [25, 53].

\section{4. $m i R-544$ and $m i R-1202$}

Through bioinformatics analyzes, miR-544 and miR-1202 were identified as potential apoB regulators. Transfection of HepG2 cells with these miRNAs demonstrated that miR-544 decreases APOB mRNA expression. While in miR-1202 transfected cells there was an increase in APOB mRNA expression, these data demonstrate that specific miRNAs are involved in the expression of ApoB [28].

\section{Other surrounding miRNAs and risk factors for atherosclerosis}


Diabetes mellitus has been recognized as an important risk factor for atherosclerosis. Zampetaki et al. (2010) observed that high glucose concentration reduced the miR-126 content in endothelial apoptotic bodies. Similarly, studies have shown that in patients with pre-diabetes mellitus there was a reduction of miR-126. The miRNAs, miR-233, miR-24 and miR-92 are found in the plasma along the HDL vesicles. Zampetaki et al. (2010) shows that expression of miR-233 is deregulated in patients with diabetes mellitus and hypercholesterolemia. In patients with insulin resistance, overexpression of miR-233 in adipocytes was associated with decreased GLUT4, an insulin-regulated glucose transporter [3, 18]. The study by Wen et al. (2015) was performed with 121 patients, and indicated high levels of miR-233 in obese individuals when compared to control [54]. Thus, these articles suggest that miR-233 may be a biomarker and target of therapies for treating obesity, diabetes and hypercholesterolemia, important pathologies related to progression of atherosclerosis.

Accumulation of LDL in the artery wall and its subsequent oxidation (ox-LDL) leads to greater activation of the vascular wall. The work of Loyer et al. (2014) shows that in hypercholesterolemic mice with LDLR -/- there was an increase in the expression of miR-92a in the bifurcations and ramifications of the arteries, areas prone to atheroma plaque formation due to ox-LDL. In addition, the expression of miR-92 was regulated by the oxidation of LDL. For Winther et al. (2014) the miR-92 inhibition is shown to be associated with reduced endothelial inflammation, in addition to preventing monocyte and macrophage adhesion during atherosclerotic plaque formation. Using PCR array, Niculescu et al. (2015) observed that miR-92a and miR-486 are surrounding miRNAs bound to HDL vesicles, most expressed in patients who present stable and unstable angina, acute myocardial infarction and heart failure. Author suggests that the miRNAs can be used as biomarkers of inflammation and endothelial dysfunction, since they can be detected in the plasma through the HDL vesicles.

\section{Conclusion}

In this review, we highlighted the role of miR-30c, miR-34 and miR-122 in decreasing plasma LDL-C by inhibiting secretion of lipoproteins containing APOB100. However, miR-34 and miR-122 were also related to the development of hepatic steatosis, a risk factor for cardiovascular diseases. While overexpression of miR-148a, miR-27a/b and miR-185 were associated with a decrease in the supply of LDLR, leading to the onset of hypercholesterolemic main cause of atherosclerosis. Detection of the expression profile of these mi-RNAS can be used as a biomarker for disorders linked to c-LDL uptake and future anti-miRNA therapies may be used in the treatment of atherosclerosis. Given the importance of these miRNAs, additional studies are needed to characterize other miRNAs in the pathway PCSK9-LDLR-APOB100 that may have contributed to the atherosclerotic disease.

Acknowledgments: This work was supported by Coordenação de Aperfeiçoamento de Pessoal de Nível Superior (CAPES, Brazil). Pró-Reitoria de Pesquisa da Universidade Federal do Pará (PROPESP-UFPA, Brazil. Postgraduate course in genetics and molecular biology (PPGBM-UFPA) Laboratory of Pharmacologic Molecular (LFM-UFPA).

Author Contributions: Maria Elisabete Silva Santos researched the content, wrote the manuscript, Ricardo Sousa de Oliveira Paraense designed tables and researched the contente, Eric Artur Cortinhas-Alves, Danilo Leôncio Aguiar Pereira, edited, revised and approved the final version of the review.

Conflicts of Interest: The authors declare no conflict of interest.

$\begin{array}{ll}\text { Abbreviations } & \\ \text { miRNAs } & \text { microRNA } \\ \text { LDL } & \text { Low-density lipoprotein } \\ \text { DCV } & \text { Cardiovascular disease } \\ \text { PCSK9 } & \text { Protein convertase subtilisina/kexina type } 9 \\ \text { LDLR } & \text { Low-density lipoprotein Receptor }\end{array}$


APOB

MTTP

EC

VSMC

DGCR8

RISC

SREBPs

HMGCR

ABCA1

HDL

SIK1

\section{Apolipoprotein B}

Microsomal triglyceride transfer protein

Endothelial cells

Vascular smooth muscle cells

DiGeorge syndrome critical region gene 8

RNA-Induced Silencing Complex

Inding proteins to the sterol regulatory element

Hydroxy-3-methylglutaryl CoA reductase

ATP-binding cassette transporter A1

High-density lipoprotein

Salt-inducible kinase 1 


\section{References}

1. Mozaffarian, D.; Benjamin E.J.; Go A.S.; Arnett D.K.; Blaha M.J.; Cushman M.; de Ferranti S.; Després J.P.; Fullerton H.J.; Howard V.J.; Huffman M.D.; Judd S.E.; Kissela B.M.; Lackland D.T.; Lichtman J.H.; Lisabeth L.D.; Liu S.; Mackey R.H.; Matchar D.B.; McGuire D.K.; Mohler E.R. 3rd; Moy C.S.; Muntner P.; Mussolino M.E.; Nasir K.; Neumar R.W.; Nichol G.; Palaniappan L.; Pandey D.K.; Reeves M.J.; Rodriguez C.J.; Sorlie P.D.; Stein J.; Towfighi A.; Turan T.N.; Virani S.S.; Willey J.Z.; Woo D.; Yeh R.W.; Turner M.B. Heart Disease and Stroke Statistics--2015 Update: A Report From the American Heart Association. Circulation 2015, v. 131(4), p. e29-322. DOI: 10.1161/CIR.0000000000000152. available online: http://circ.ahajournals.org/content/131/4/e29.long (accessed on 11 september 2016 ).

2. Tian, N.; Li, X.; Luo, Y.; Han, Z.; Li, Z.; Fan, C. Curcumin regulates the metabolism of low density lipoproteins by improving the C-to-U RNA editing efficiency of apolipoprotein B in primary rat hepatocytes. Mol. Med. Rep. 2014, v. 9(1), p.1326. DOI: 10.3892/mmr.2013.1754. available online: https://www.spandidos-publications.com/mmr/9/1/132 (accessed on 11 december 2016 ).

3. Lu, H.; Buchan, R.J.; Cook, S. A. MicroRNA-223 regulates Glut4 expression and cardiomyocyte glucose metabolism: Cardiovasc. Res. 2010, v. 86(3), p. 410-20. DOI:10.1093/cvr/cvq010. available online: https:/academic.oup.com/cardiovascres/article-lookup/DOI/10.1093/cvr/cvq010 (accessed on 13 december $2016)$.

4. Ren, J.; Zhang, J.; Xu, N.; Han, G.; Geng, Q.; Song, J.; Li, S.; Zhao, J.; Chen, H. Signature of circulating MicroRNAs as potential biomarkers in vulnerable coronary artery disease. PLoS One. 2013, v. 8(12), p. e80738. DOI:10.1371/journal.pone.0080738. available online: http://journals.plos.org/plosone/article?id=10.1371/journal.pone.0080738 (accessed on 15 december 2016 ).

5. Wagschal, A.; Najafi-Shoushtari, S.H.; Wang, L.; Goedeke, L.; Sinha, S.; deLemos, A.S.; Black, J.C.; Ramírez, C.M.; Li, Y.; Tewhey, R.; Hatoum, I.; Shah, N.; Lu, Y.; Kristo, F.; Psychogios, N.; Vrbanac, V.; Lu, Y.C.; Hla, T.; de Cabo, R.; Tsang, J.S.; Schadt, E.; Sabeti, P.C.; Kathiresan, S.; Cohen, D.E.; Whetstine, J.; Chung, R.T.; Fernández-Hernando, C.; Kaplan, L.M.; Bernards, A.; Gerszten, R.E.; Näär, A.M. Genome-wide identification of microRNAs regulating cholesterol and triglyceride homeostasis. Nat. Med. 2015, v. 21(11), p. 1290-7. DOI: 10.1038/nm.3980. available online: https://www.nature.com/nm/journal/v21/n11/full/nm.3980.html (accessed on 15 december 2016 ).

6. Karbiener, M.; Neuhold, C.; Opriessnig, P.; Prokesch, A.; Bogner-Strauss, J. G.; Scheideler, M. MicroRNA-30c promotes human adipocyte differentiation and co-represses PAI-1 and ALK2. RNA Biol. 2011, v. 8(5), p. 850-60. DOI: 10.4161/rna.8.5.16153. available online: http://www.tandfonline.com/doi/abs/10.4161/rna.8.5.16153 (accessed on 11 december 2016 ).

7. Niculescu, L.S.; Simionescu, N.; Sanda, G.M.; Carnuta, M.G.; Stancu, C.S.; Popescu, A.C.; Popescu, M.R.; Vlad, A.; Dimulescu, D.R.; Simionescu, M.; Sima A.V. MiR-486 and miR-92a Identified in Circulating HDL Discriminate between Stable and Vulnerable Coronary Artery Disease Patients. PLoS One. 2015, v. 10(10), p. e0140958. DOI: 10.1371/journal.pone.0140958. available online: http://journals.plos.org/plosone/article?id=10.1371/journal.pone.0140958 (accessed on 12 december 2016 ).

8. Rusinov, V.; Baev, V.; Minkov, I.N.; Tabler, M. MicroInspector: a web tool for detectionofmiRNAbinding sites in an RNA sequence. Nucleic Acids Res. 2005, v. 33, (Web Server Issue): W696-W700. DOI: 10.1093/nar/gki364. available online: https:/www.ncbi.nlm.nih.gov/pmc/articles/PMC1160125/ (accessed on 12 February 2017 ).

9. Huntley, R.P.; Sitnikov, D.; Orlic-Milacic, M.; Balakrishnan, R.; D'Eustachio, P.; Gillespie, M.E.; Howe, D.; Kalea, A.Z.; Maegdefessel, L.; Osumi-Sutherland, D.; Petri, V.; Smith, J.R.; Van Auken, K.; Wood, V.; Zampetaki, A.; Mayr, M.; Lovering, R.C. Guidelines for the functional annotation of microRNAs using the Gene Ontology. RNA. 2016, v. 22 (5), p. 667-76. DOI: 10.1261/rna.055301.115. available online: https://www.ncbi.nlm.nih.gov/pmc/articles/PMC4836642/ (accessed on 14 February 2017 ).

10. Rodriguez, A.; Griffiths-Jones S.; Ashurst J.L.; Bradley A. Identification of Mammalian microRNA Host Genes and Transcription Units. Genome Res. 2004, v. 14(10A), p. 1902-10. available online: https://www.ncbi.nlm.nih.gov/pmc/articles/PMC524413/ (accessed on 16 February 2017 ).

11. Gregory, R.I.; Chendrimada, T.P.; Cooch, N.; Shiekhattar, R. Human RISC couples microRNA biogenesis and post transcriptional gene silencing. Cell. 2005, v. 123(4), p. 631-40. DOI: 10.1016/j.cell.2005.10.022. available

online: 
http://www.cell.com/cell/abstract/S0092-8674(05)01109-8? returnURL=http\%3A\%2F\%2Flinkinghub.elsevie r.com\%2Fretrieve\%2Fpii\%2FS0092867405011098\%3Fshowall\%3Dtrue (accessed on 18 January 2017 ).

12. Arteaga-Vázquez, M.; Caballero-Pérez, J.; Vielle-Calzadaa, J.P. A Family of MicroRNAs Present in Plants and Animals. Plant Cell. 2006, v. 18(12), p. 3355-69. DOI: 10.1105/tpc.106.044420. available online: https://www.ncbi.nlm.nih.gov/pmc/articles/PMC1785418/ (accessed on 22 January 2017 ).

13. Pacholewska, A.; Mach, N.; Mata, X.; Vaiman, A.; Schibler, L.; Barrey, E.; Gerber, V. Novel equine tissue miRNAs and breed-related miRNA expressed in serum. BMC Genomics. 2016, v. 17(1), p. 831. DOI 10.1186/s12864-016-3168-2. available online: https://bmcgenomics.biomedcentral.com/articles/10.1186/s12864-016-3168-2 (accessed on 19 January 2017 ).

14. de Gonzalo-Calvo, D.; Cenarro, A.; Garlaschelli, K.; Pellegatta, F.; Vilades, D.; Nasarre, L.; Camino-Lopez, S.; Crespo, J.; Carreras, F.; Leta, R.; Catapano, A.L.; Norata, G.D.; Civeira, F.;Llorente-Cortes V. Translating the microRNA signature of microvesicles derived from human coronary artery smooth muscle cells in patients with familial hypercholesterolemia and coronary artery disease. J Mol Cell Cardiol. 2017, v. 106, p. 55-67. DOI: 10.1016/j.yjmcc.2017.03.005. available online: http://www.jmmc-online.com/article/S0022-2828(17)30060-3/abstract (accessed on 12 January 2017 ).

15. Vickers, K.C.; Shoucri, B.M.; Levin, M.G.; Wu, H.; Pearson, D.S.; Osei-Hwedieh, D.; Collins F.S.; Remaley, A.T.; Sethupathy, P. MicroRNA-27b is a regulatory hub in lipid metabolism and is altered in dyslipidemia. Hepatology. 2013, v. 57(2), p. 533-42. DOI: 10.1002/hep.25846. available online: https://www.ncbi.nlm.nih.gov/pmc/articles/PMC3470747/ (accessed on 18 March 2017 ).

16. Mitchell, P.S.; Parkin, R.K.; Kroh, E.M.; Fritz, B.R.; Wyman, S.K.; Pogosova-Agadjanyan, E.L.; Peterson, A.; Noteboom, J.; O'Briant, K.C.; Allen, A.; Lin, D.W.; Urban, N.; Drescher, C.W.; Knudsen, B.S.; Stirewalt, D.L.; Gentleman, R.; Vessella, R.L.; Nelson, P.S.; Martin, D.B.; Tewari, M. Circulating microRNAs as stable blood-based markers for cancer detection. Proc. Natl. Acad. Sci. U. S. A. 2008, v. 105(30), p. 10513-8. DOI: 10.1073/pnas.0804549105. available online: http://www.pnas.org/content/105/30/10513 (accessed on 15 March 2017 ).

17. Weber, J.A.; Baxter, D.H.; Zhang, S.; Huang, D.Y.; Huang, K.H.; Lee, M.J.; Galas, D.J.; Wang, K. The microRNA spectrum in 12 body fluids. Clin. Chem. 2010, v. 56 (11), p. 1733-41. DOI: 10.1373/clinchem.2010.147405. available online: https://www.ncbi.nlm.nih.gov/pmc/articles/PMC4846276/ (accessed on 17 March 2017).

18. Liu, Y.; Gao, G.; Yang, C.; Zhou, K.; Shen, B.; Liang, H.; Jiang, X. The role of circulating microRNA-126 (miR-126): a novel biomarker for screening prediabetes and newly diagnosed type 2 diabetes mellitus. Int. J. Mol. Sci. 2014, v. 15(6), p. 10567-77. DOI: 10.3390/ijms150610567. available online: https://www.ncbi.nlm.nih.gov/pmc/articles/PMC4100169/ (accessed on 1 March 2017).

19. Goedeke, L.; Rotllan, N.; Canfrán-Duque, A.; Aranda, J.F.; Ramírez, C.M.; Araldi, E.; Lin, C.S.; Anderson, N.N.; Wagschal, A.; de Cabo, R.; Horton, J.D.; Lasunción, M.A.; Näär, A.M.; Suárez, Y.; Fernández-Hernando, C. MicroRNA-148a regulates LDL receptor and ABCA1 expression to control circulating lipoprotein levels. Nat. Med. 2015, v. 21(11), p. 1280-9. DOI: 10.1038/nm.3949. available online: https://www.nature.com/nm/journal/v21/n11/full/nm.3949.html (accessed on 5 March 2017 ).

20. Wang, Y.C.; Li, Y.; Wang, X.Y.; Zhang, D.; Zhang, H.; Wu, Q.; He, Y.Q.; Wang, J.Y.; Zhang, L.; Xia, H.; Yan, $\mathrm{I} . ; \underline{\mathrm{Li}, \mathrm{X}}$; $\underline{\text { Ying, } \mathrm{H}}$. Circulating miR-130b mediates metabolic crosstalk between fat and muscle in overweight/obesity. Diabetologia. 2013, v. 56(10), p. 2275-85. DOI: 10.1007/s00125-013-2996-8. available online: https://link.springer.com/article/10.1007\%2Fs00125-013-2996-8 (accessed on 10 March 2017 ).

21. Moura, J.; Børsheim, E.; Carvalho, E. The Role of MicroRNAs in Diabetic Complications-Special Emphasis on Wound Healing. Genes (Basel). 2014, v. 5(4), p. 926-56. DOI: 10.3390/genes5040926. available online: https://www.ncbi.nlm.nih.gov/pmc/articles/PMC4276920/ (accessed on 29 March 2017 ).

22. Zhang, T.; Li, L.; Shang, Q.; Lv, C.; Wang, C.; Su, B. Circulating miR-126 is a potential biomarker to predict the onset of type 2 diabetes mellitus in susceptible individuals. Biochem Biophys Res Commun. 2015, v. 463(1-2), p. 60-3. DOI: 10.1016/j.bbrc.2015.05.017. available online: http://www.sciencedirect.com/science/article/pii/S0006291X15009237 (accessed on 12 February 2017 ).

23. Xie, W.; Li, L.; Zhang, M.; Cheng, H.P.; Gong, D.; Lv, Y.C.; Yao, F.; He, P.P.; Ouyang, X.P.; Lan, G.; Liu, D.; Zhao, Z.W.; Tan, Y.L.; Zheng, X.L.; Yin, W.D.; Tang, C.K. MicroRNA-27 Prevents Atherosclerosis by Suppressing Lipoprotein Lipase-Induced Lipid Accumulation and Inflammatory Response in Apolipoprotein E Knockout Mice. PLoS One. 2016, v. 11(6), p. 1-20. DOI: 10.1371/journal.pone.0157085. available online: http://journals.plos.org/plosone/article?id=10.1371/journal.pone.0157085 (accessed on 12 February 2017). 
24. Tsai, W.C.; Hsu, S.D.; Hsu, C.S.; Lai, T.C.; Chen, S.J.; Shen R.; Huang, Y.; Chen, H.C.; Lee, C.H.; Tsai, T.F.; Hsu, M.T.; Wu, J.C.; Huang, H.D.; Shiao, M.S.; Hsiao, M.; Tsou, A.P. MicroRNA-122 plays a critical role in liver homeostasis and hepatocarcinogenesis. J. Clin. Invest. 2012, v. 122(8), p. 2884-97. DOI: 10.1172/JCI63455. available online: https://www.ncbi.nlm.nih.gov/pmc/articles/PMC3408747/ (accessed on 14 February 2017).

25. Xu, Y.; Zalzala, M.; Xu, J.; Li, Y.; Yin, L.; Zhang, Y. A metabolic stress-inducible miR-34a-HNF4alpha pathway regulates lipid and lipoprotein metabolism. Nat. Commun. 2015, v. 6, p. 7466. DOI: 10.1038/ncomms8466. available online: https://www.nature.com/articles/ncomms8466 (accessed on 18 March 2017 ).

26. Soh, J. and Hussain, M.M. Supplementary site interactions are critical for the regulation of microsomal triglyceride transfer protein by microRNA-30c. Nutri Metab (Lond). 2013, v. 10, p. 56. DOI: 10.1186/1743-7075-10-56. available online: (accessed on 10 March 2017 ).

27. Soh, J.; Iqbal, J.; Queiroz, J.; Fernandez-Hernando, C.; Hussain, M.M. MicroRNA-30c reduces hyperlipidemia and atherosclerosis in mice by decreasing lipid synthesis and lipoprotein secretion. Nat. Med. 2013, v. 19(7), p. 892-900. DOI: 10.1038/nm.3200. available online: https://www.nature.com/nm/journal/v19/n7/full/nm.3200.html (accessed on 9 March 2017).

28. Basir, S.A.; Asante, T.; Adeli, K. Abstract 1: Role of MicroRNAs in Postranscriptional Regulation on Apolipoprotein B-100 mRNA. Aterioclerosis, Thrombosis, and Vascular Biology. 2014, v. 34(A1). available online: http://atvb.ahajournals.org/content/34/Suppl 1/A1 (accessed on 23 March 2017 ).

29. Goedeke, L.; Rotllan, N.; Canfrán-Duque, A.; Aranda, J.F.; Ramírez, C.M.; Araldi, E.; Lin, C.S.; Chin-Sheng; Anderson, N.N.; Wagschal, A.; de Cabo, R.; Horton, J.D.; Lasunción, M.A.; Näär, A.M.; Suárez, Y.; Fernández-Hernando C. miR-27b inhibits LDLR and ABCA1 expression but does not influence plasma and hepatic lipid levels in mice. Atherosclerosis. 2015, v. 243(2), p. 499-509. DOI: 10.1016/j.atherosclerosis.2015.09.033. available online: https://www.ncbi.nlm.nih.gov/pmc/articles/PMC4975922/ (accessed on 28 March 2017 ).

30. Kuan, Y.C.; Hashidume, T.; Shibata, T.; Uchida, K.; Shimizu, M.; Inoue, J.; Sato, R.;. Heat Shock Protein 90 Modulates Lipid Homeostasis by Regulating the Stability and Function of Sterol Regulatory Element-binding Protein (SREBP) and SREBP Cleavage-activating Protein. J Biol Chem. 2016, v. 292(7), p. 3016-28. DOI: 10.1074/jbc.M116.767277. available online: http://www.jbc.org/content/early/2016/12/21/jbc.M116.767277.abstract (accessed on 29 March 2017).

31. Haas, M.; Mary, E.; Levenson, A.E.; Sun, X.; Liao, W.H.; Rutkowski, J.M.; De Ferranti, S.D.; Schumacher, V.A.; Scherer, P.E.; Salant, D.J.; Biddinger, S.B. Role of Proprotein Convertase Subtilisin/Kexin Type 9 in Nephrotic Syndrome-Associated Hypercholesterolemia. Circulation. 2016, v. 134(1), p. 61-72. DOI: 10.1161/CIRCULATIONAHA.115.020912. available

online: http://circ.ahajournals.org/content/134/1/61.long (accessed on 16 March 2017 ).

32. Seidah, N.G.; Sadr, M.S.; Chretien, M.; Mbikay M. The multifaceted proprotein convertases: their unique, redundant, complementary, and opposite functions. J Bio. Chem. 2013, v. 288, p. 21473-81. DOI: 10.1074/jbc.R113.481549. available online: http://www.jbc.org/content/early/2013/06/17/jbc.R113.481549 (accessed on 15 March 2017 ).

33. Lagace, T.A. PCSK9 and LDLR degradation: regulatory mechanisms in circulation and in cells. Curr Opin Lipidol. 2014, v. 25(5), p. 387-93. DOI: 10.1097/MOL.0000000000000114. available online: https://www.ncbi.nlm.nih.gov/pmc/articles/PMC4166010/ (accessed on 2 March 2017).

34. Poirier, S.; Mamarbachi, M.; Chen, W.T.; Lee, A.S.; Mayer G. GRP94 Regulates Circulating Cholesterol Levels through Blockade of PCSK9-Induced LDLR Degradation. Cell Rep. 2015, v. 13(10), p. 2064-71. DOI: 10.1016/j.celrep.2015.11.006. available online: http://www.cell.com/cell-reports/abstract/S2211-1247(15)01293-0? returnURL=http\%3A\%2F\%2Flinkinghu b.elsevier.com\%2Fretrieve\%2Fpii\%2FS2211124715012930\%3Fshowall\%3Dtrue (accessed on 27 March 2017 ) .

35. Everett, B.M.; Smith, R.J.; Hiatt W.R. Reducing LDL with PCSK9 Inhibitors--The Clinical Benefit of Lipid Drugs. N Engl J Med. 2015, v. 373, p. 1588-91. DOI: 10.1056/NEJMp1508120. available online: http://www.nejm.org/doi/full/10.1056/NEJMp1508120\#t=article (accessed on 27 March 2017 ).

36. Robinson, J.G.; Farnier, M.; Krempf, M.; Bergeron, J.; Luc, G.; Averna, M.; Stroes, E.S.; Langslet, G.; Raal, F.J.; El Shahawy, M.; Koren, M.J.; Lepor, N.E.; Lorenzato, C.; Pordy, R.; Chaudhari, U.; Kastelein, J.J.; ODYSSEY LONG TERM Investigators. Efficacy and safety of alirocumab in reducing lipids and 
cardiovascular events. N Engl J Med. 2015, v. 372(16), p. 1489-99. DOI: 10.1056/NEJMoa1501031. available online: http://www.nejm.org/doi/full/10.1056/NEJMoa1501031 (accessed on 29 March 2017).

37. Yang, M.; Liu, W.; Pellicane, C.; Sahyoun, C.; Joseph, B.K.; Gallo-Ebert, C.; Donigan, M.; Pandya, D.; Giordano, C.; Bata, A.; Nickels, J.T. Jr. Identification of miR-185 as a regulator of de novo cholesterol biosynthesis and low density lipoprotein uptake. J. Lipid Res. 2014, v. 55(2), p. 226-238. DOI:10.1194/jlr.M041335. available online: https:/www.ncbi.nlm.nih.gov/pmc/articles/PMC3886661/ (accessed on 27 March 2017 ).

38. Tate, R.; Rotondo, D.; Davidson, J. Regulation of lipid metabolism by microRNAs. Curr Opin Lipidol. 2015, v. 26(3), p. 243-4. DOI: 10.1097/MOL.0000000000000186. available online: http://journals.lww.com/co-lipidology/Citation/2015/06000/Regulation of lipid metabolism by microRN As.15.aspx (accessed on 18 March 2017 ).

39. Vickers, K.C.; Moore, K.J. Small RNA Overcomes the Challenges of Therapeutic Targeting of Microsomal Triglyceride Transfer Protein Circulation research. 2013, v. 113(11), p. 1189-1191. DOI:10.1161/CIRCRESAHA.113.302732. available online: https://www.ncbi.nlm.nih.gov/pmc/articles/PMC4043302/ (accessed on 13 March 2017 ).

40. Zhang, M.; Wu, J.F.; Chen, W.J.; Tang, S.L.; Mo, Z.C.; Tang, Y.Y.; Li, Y.; Wang, J.L.; Liu, X.Y.; Peng, J.; Chen, K.; He, P.P.; Lv, Y.C.; Ouyang, X.P.; Yao, F.; Tang, D.P.; Cayabyab, F.S.; Zhang, D.W.; Zheng, X.L.; Tian, G.P.; Tang, C.K. MicroRNA-27a/b regulates cellular cholesterol efflux, influx and esterification/hydrolysis in THP-1 macrophages. Atherosclerosis. 2014, v. 234 (1), p. 54-64. DOI: 10.1016/j.atherosclerosis.2014.02.008. available online: http://www.atherosclerosis-journal.com/article/S0021-9150(14)00106-3/abstract (accessed on 19 March 2017 ).

41. Alvarez, M.L.; Khosroheidari, M.; Eddy, E.; Done, S.C. MicroRNA-27a decreases the level and efficiency of the LDL receptor and contributes to the dysregulation of cholesterol homeostasis. Atherosclerosis. 2015, v. 242(2), p. 595-604. DOI:10.1016/j.atherosclerosis.2015.08.023. available online: http://www.atherosclerosis-journal.com/article/S0021-9150(15)30086-1/abstract (accessed on 22 March 2017).

42. Shirasaki, T.; Honda, M.; Shimakami, T.; Horii, R.; Yamashita, T.; Sakai, Y.; Sakai, A.; Okada, H.; Watanabe, R.; Murakami, S.; Yi, M.; Lemon, S.M.; Kaneko, S. MicroRNA-27a regulates lipid metabolism and inhibits hepatitis C virus replication in human hepatoma cells. I Virol. 2013, v. 87(9), p. 5270-86. DOI: 10.1128/JVI.03022-12. available online: http://jvi.asm.org/content/87/9/5270.long (accessed on 12 March 2017 ).

43. Yu, M.; Liang, W.; Xie, Y.; Long, Q.; Cheng, X.; Liao, Y.H.; Yuan J. Circulating miR-185 might be a novel biomarker for clinical outcome in patients with dilated cardiomyopathy. Sci Rep. 2016, v. 6, p. 33580. DOI:10.1038/srep33580. available online: https://www.ncbi.nlm.nih.gov/pmc/articles/PMC5028782/ (accessed on 1 March 2017 ).

44. Kim, J.O.; Song, D.W.; Kwon, E.J.; Hong, S.E.; Song, H.K.; Min, C.K.; Kim, D.H. miR-185 plays an anti-hypertrophic role in the heart via multiple targets in the calcium-signaling pathways. PLoS One. 2015, v. 10(3), p. e0122509. DOI:10.1371/journal.pone.0122509. available online: http://journals.plos.org/plosone/article?id=10.1371/journal.pone.0122509 (accessed on 1 March 2017 ).

45. Li, M.; Wang, Q.; Liu, S.A.; Zhang, J.Q.; Ju, W.; Quan, M.; Feng, S.H.; Dong, J.L.; Gao, P.; Cheng, J. MicroRNA-185-5p mediates regulation of SREBP2 expression by hepatitis C virus core protein. World J Gastroenterol. 2015, v. 21(15), p. 4517-25. DOI: 10.3748/wjg.v21.i15.4517. available online: https://www.ncbi.nlm.nih.gov/pmc/articles/PMC4402298/ (accessed on 15 March 2017 ).

46. Zhou, L.; Irani, S.; Sirwi, A.; Hussain, M.M. MicroRNAs regulating apolipoprotein B-containing lipoprotein production. Biochim. BBA - Molecular and cell biology of lipids. 2016, v. 1861(12B), 2062-68. DOI: 10.1016/j.bbalip.2016.02.020. available online: http://www.sciencedirect.com/science/article/pii/S1388198116300476 (accessed on 15 March 2017 ).

47. Huang, Y.; Chen, J.; Zhou, Y.; Yu, X.; Huang, C.; Li, J.; Feng Y. Circulating miR-30 is related to carotid artery atherosclerosis. Clin Exp Hypertens. 2016, v. 38(5), 489-94. DOI: 10.3109/10641963.2016.1163370. available online: https://www.ncbi.nlm.nih.gov/labs/articles/27379414/ (accessed on 15 March 2017).

48. Zampetaki, A.; Kiechl, S.; Drozdov, I.; Willeit, P.; Mayr, U.; Prokopi, M.; Mayr, A.; Weger, S.; Oberhollenzer, F.; Bonora, E.; Shah, A.; Willeit, J.; Mayr, M. Plasma microRNA profiling reveals loss of endothelial miR-126 and other microRNAs in type 2 diabetes. Circ Res. 2010, v. 107(6), p. 810-17. DOI: 
10.1161/CIRCRESAHA.110.226357. available online: http://circres.ahajournals.org/content/107/6/810.long (accessed on 2 March 2017 ).

49. Elmén J1, Lindow M, Schütz S, Lawrence M, Petri A, Obad S, Lindholm M, Hedtjärn M, Hansen HF, Berger U, Gullans S, Kearney P, Sarnow P, Straarup EM, Kauppinen S. LNA-mediated microRNA silencing in non-human primates. Nature. 2008, v. 452, p.896-9. DOI: 10.1038/nature06783. available online: https://www.nature.com/nature/journal/v452/n7189/full/nature06783.html (accessed on 17 March 2017).

50. Esau, C.; Davis, S.; Murray, S.F.; Yu, X.X.; Pandey, S.K.; Pear, M.; Watts, L.; Booten, S.L.; Graham, M.; McKay, R.; Subramaniam, A.; Propp, S.; Lollo, B.A.; Freier, S.; Bennett, C.F.; Bhanot, S.; Monia, B.P. miR-122 regulation of lipid metabolism revealed by in vivo antisense targeting. Cell Metab. 2006, v. 3(2), p. 87-98. DOI: 10.1016/j.cmet.2006.01.005. available online: http://www.cell.com/cell-metabolism/abstract/S1550-4131(06)00029-5? returnURL=http\%3A\%2F\%2Flinki nghub.elsevier.com\%2Fretrieve\%2Fpii\%2FS1550413106000295\%3Fshowall\%3Dtrue (accessed on 7 March 2017).

51. Hueging, K.; Doepke, M.; Vieyres, G.; Bankwitz, D.; Frentzen, A.; Doerrbecker, J.; Gumz, F.; Haid, S.; Wolk, B.; Kaderali, L.; Pietschmann T. Apolipoprotein E codetermines tissue tropism of hepatitis $C$ virus and is crucial for viral cell-to-cell transmission by contributing to a postenvelopment step of assembly. J Virol. 2014, v. 88(3), p. 1433-46. DOI: 10.1128/JVI.01815-13. available online: https://www.ncbi.nlm.nih.gov/pmc/articles/PMC3911621/ (accessed on 26 March 2017).

52. Lee, T.H.; Matta, B.; King, B.D.; Hodges, M.R.; Tillmann, H.L.; Patel, K. MicroRNA-122 associates with serum apolipoprotein B but not liver fibrosis markers in CHC genotype 1 infection. J Med Virol. 2015, v. 87(10), 1722-6. DOI: 10.1002/jmv.24230. available http://onlinelibrary.wiley.com/doi/10.1002/jmv.24230/abstract;jsessionid=89A697F21EF285D7D13D15EA2 F6932E0.f04t01 (accessed on 27 March 2017 ).

53. Bernardo, B.C.; Gao, X.M.; Winbanks, C.E.; Boey, E.J.; Tham, Y.K.; Kiriazis, H.; Gregorevic, P.; Obad, S.; Kauppinen, S.; Du, X.J.; Lin, R.C.; McMullen, J.R. Therapeutic inhibition of the miR-34 family attenuates pathological cardiac remodeling and improves heart function. Proc. Natl. Acad. Sci. U. S. A. 2012, v. 109(43), p. 17615-20. DOI: 10.1073/pnas.1206432109. available online: http://www.pnas.org/content/109/43/17615.long (accessed on 4 March 2017 ).

54. Wen, D.; Qiao, P.; Wang, L. Circulating microRNA-223 as a potential biomarker for obesity. Obes Res Clin Pract. 2015, v. 9(4), p. 398-404. DOI: 10.1016/j.orcp.2015.01.006. available online: http://www.obesityresearchclinicalpractice.com/article/S1871-403X(15)00020-4/fulltext (accessed on ).

55. Loyer, X.; Potteaux, S.; Vion, A.C.; Guérin, C.L.; Boulkroun, S.; Rautou, P.E.; Ramkhelawon, B.; Esposito, B.; Dalloz, M.; Paul, J.L.; Julia, P.; Maccario, J.; Boulanger, C.M.; Mallat, Z.; Tedgui, A. Inhibition of microRNA-92a prevents endothelial dysfunction and atherosclerosis in mice. Circ Res. 2014, v. 114(3), p. 434-43. DOI: 10.1161/CIRCRESAHA.114.302213. available online: http://circres.ahajournals.org/content/114/3/434.long (accessed on 5 March 2017).

56. de Winther, M.P.; Lutgens, E. MiR-92a: at the heart of lipid-driven endothelial dysfunction: Circulation research. 2014, v. 114(3), 399-401. DOI: 10.1161/CIRCRESAHA.114.303125. available online: http://circres.ahajournals.org/content/114/3/399.long (accessed on 5 March 2017 ). 